\title{
Interactive comment on "Physical laws for precursory phenomena of impending large earthquakes and their applications to predictions" by Fumihide Takeda
}

\section{F. Takeda}

epi21@cap.ocn.ne.jp

Received and published: 21 April 2018

Final responses to referees \#1 and \#2 are in pdf.

Please also note the supplement to this comment:

https://www.nat-hazards-earth-syst-sci-discuss.net/nhess-2017-454/nhess-2017-454-

AC3-supplement.pdf 